$\xi=-1$

\title{
On the Possibility of a Supranational Collective Bargaining of Labour Relations within the BRICS Countries (The Experience of China, India and South Africa)
}

\author{
Evgenia Evgenevna Frolova, Ksenia Mikhailovna Belikova, Natalia Vladimirovna Badaeva \\ Peoples' Friendship University of Russia, Miklukho-Maklaya str., 6, Moscow, Russia, 117198
}

\begin{abstract}
The development of transnational corporations (TNC) raises the question of an effective system of organization management, in particular, in countries - members of the BRICS. The results of the study showed the use of a collective labor contract in organizations in India, China, South Africa is not widespread. Regulation of social and labor relations is limited to national features, mentality, traditions. For example, in China workers, due to the prevailing attitude and philosophy, do not seek to use a collective labor contract to regulate the relations with the employer. Based on a number of reasons shown in the article, the authors consider that most probably no major changes related to the regulation of labor relations in these countries will occur in the near future.
\end{abstract}

Keywords: BRICS, labor contract, transnational corporations

\section{1. .Introduction}

IVth Trade Union Forum of BRICS countries in its Declaration (art 14) adopted on July 9, 2015 in Ufa, Russian Federation [1], noted that "...further development of the Third industrial revolution ... currently make it possible both to reach new levels in automation, robotics, nanotechnology, new materials, energy consumption standards and organization of production processes... and boost production changes, concentration and centralization of capital, competition in the sphere of monopolies and oligopolies, inevitably affecting employment and workers' incomes everywhere." It's also noted that "Trade unions are an effective force in defending democracy and in the fight for justice and ecologically sustainable future. Trade unions of BRICS countries are ready to take their rightful place in this fight and, first and foremost, in the field of decent jobs creation, occupational safety and health, protection of workers' interests - including those of women and youth - in order to achieve social justice and sustainable development." (Art 5 of the Declaration).

At present BRICS countries reached a certain concentration and centralization of capital and production, numerous and wellknown transnational corporations (hereinafter TNCs) are acting [2]. At large TNCs international trade Union secretariats, councils, committees, coordinating activities of the trade unions of different countries are acting. They collect and store information necessary for conducting collective negotiations, etc.

That's why it is interesting to look at and think over whether it is possible to elaborate and fix in any generalized and unified form: 1) employment conditions in both parent companies and branches of international corporations; 2) approaches to issues affecting the geographical distribution of production (reorganization, liquidation, etc. of enterprises) and investment (purchase of the "ongoing business"); 3) issues of filling by the contents of charters of enterprises and their application; consolidation of the measures aimed at improving working conditions (including tariff regulation) in order to decide whether such oases of the representation of TNCs employees could in the future become the organs of the collective bargaining representation of employees in their re-negotiations with TNCs of BRICS countries.

These cases are well-known in European legal order, thus, it's an agreement of trade unions with the management of TNC "Glaverbel Glass Company" that included enterprises of Austria, Belgium, Italy, France and Germany, likewise three framework collective agreements concluded by the European Trade Union Confederation (ETUC) and European social partners representing employers (e g Union of European Confederation of Entrepreneurs / Union of Industrial and Employers' Confederations of Europe (UNICE) (now known as BUSINESSEUROPE): on parental leave in 1995 (renovated in 2009); on part-time work in 1997 and on fixed-term contracts in 1999 (later on became Council directives) [3].

Some researchers treat the idea of the proliferation of such an agreements with skepticism, pointing out a number of problems that hinder their conclusion, including the variety of conditions of work and employment in different countries that prevent the fixation of their community, and different levels of collective bargaining (national, local, etc.); and different contents of collective agreements in the countries with different legal systems with regard to various combinations of its provisions, based on disparate and sometimes even conflicting norms of national labour legislation (with regard to the order of its conclusion, detention of its status - whether a gentlemen's agreement or the regulatory agreement, the expiration, structure of the labour pay, etc.).

Others believe inevitable the implementation of this idea in the future, as such regulation is beneficial for the employees and may hinder the management of the TNC from taking advantages of international wage differentiation, working conditions, competition and mobility of workers from different countries. As international collective bargaining agreements are aimed at aligning of working conditions, including wages of employees of en- 
terprises of TNCs that perform an equal quantity and quality of work, but do it in different countries.

Of course, legal nature and force of such agreement is at question, the mechanism of their conclusion is unclear. How collective bargaining at international level should be organized, when entrepreneurs are a well-centralized power that possesses the economic power of financial and industrial capital and trade unions are fragmented and there is no consent among them at the national level as the idea of trade Union pluralism and unions at branch or shop principle prevail?

The way may be given to the TNCs self- restriction, which is manifested in the tendency to the unification of the terms of use of labor force on the basis of the principle of "equal pay for equal work" recognized in many countries, and a number of generally accepted international standards of the ILO - towards the internationalization of work`s value.

Difficulties in targeting these issues are increased by the lack of relevant legal provisions in both national and international acts. However, the vectors of the development of this process will be seen with time. Now let`s look at the soil and prerequisites that are available or missing within the BRICS legal systems for the implementation of this idea.

\section{Methods}

Analysis of the scope of application of the acts on labour relations of the aforementioned BRICS countries and of their general provisions based on the idea on both objective and subjective predetermination of any process. The work is done with the use of the following scientific methods: systemic analysis and synthesis of normative acts and practical materials, formal and dialectical logic: analysis, synthesis, induction, deduction, hypothesis, analogy, and special methods of legal studies - comparative legal and historical-legal, systemic analysis and interpretation of legal norms.

\section{Results and Discussion}

So collective bargaining has long been considered in India as one of the methods of industrial disputes settlement [4], it has been the subject matter of industrial adjudication since long and has been defined by our Law Courts in the form of recognition of collective bargaining: 1) "... as a technique by which dispute as to condition of employment is resolved amicably by agreement rather than coercion" (in Karnal Leather Karamchari Sangathan v. Liberty Footwear Co. [5]); 2) “....as a legitimate trade union activities, which must shun all kinds of physical threats, coercion or violence, must march with a spirit of tolerance, understanding and grace in dealings on the part of the employer..." (in Bharat Iron Works v. Bhagubhai Balubhal Patel) [5].

Thus, collective bargaining has the following characteristics: It is a process. There are several sequential steps or phases in collective bargaining, beginning with presentation of a list of demands, followed by negotiations and signing of a collective agreement, which leads to administration of the contract.

It is a bipartite process involving 2 parties. Negotiations take place between workers and their employers.

It is a collective activity. Groups of workers and employer(s) are involved in this process, and both parties act collectively.

Negotiations form the basis of collective bargaining. The process involves mutual "give and take' between labour and management through discussions that may result in compromising and accommodating situations for the other party.

Collective bargaining is a formal process by which employers and unions of workers decide to resolve their conflicts and disputes.

The process aims at establishing industrial democracy as it provides workers a forum to demand their rights.

The underlying objective of collective bargaining is always to resolve the issues between labour and management through a dia- logue, and to come to an agreement rather than strike, lock-out or other methods of coercion that disrupt industrial harmony.

For comparison, in Russia the collective-agreement regulation is exercised on the basis of collective negotiations, and thus provides employees and employers the opportunity to publicly express and harmonize their working interests. It is quite flexible because it allows to take into account features of the organization of labour and of consumption in a particular region, industry and be attentive to the local specifics, the economic and financial conditions of the employer, etc., that allows to fully realize the needs of society with regard to the public interests. In fact, collective-agreement regulation is a form of realization of principles of social partnership in the labor sphere. In India during the collective negotiations the level of wages is determined, and the victory depends, as a rule, on the actual strength of the unions and management. The importance and binding force of collective negotiations periodically emphasized in the decisions of the Supreme court of India.

Thus, in Tamilnad Electricity Workers' Federation v. Madras State Electricity Board [6] the Higher court of Madras stated that the strength of the employer prevails over the power of the employee(s) that are not unionized. Thus, it is a collective bargaining carried out in the interests of the employees that constitutes the basis of the trade Union movement. The unions can obtain real force able to confront employers in defending these interests only when legal framework for such negotiations is agreed and approved by trade unions. In Russia, as elements of the right to collective bargaining can be called the right to be engaged in collective negotiations, the right to establish and sign collective agreements, the right to determine their contents. Efficiency is determined by the fact whether such provisions change employees situation for the better.

Depending upon the coverage of the terms of agreement and involvement bargaining in different sectors may take place at different levels: unit-level, enterprise/plant-level, regional/ industrylevel or national/economy -level. Negotiations that take place at unit/plant-level result in decentralised agreements between management and enterprise-level union representatives, sometimes with the participation of the federations of unions representing other companies of the group or TNCs, for example. Agreement of this kind is represented by the first agreement of its kind between TISCO and Tata Workers Union in 1956. As it is noted in governmental report, even if collective negotiations take place at plant or enterprise level committees can achieve significant standardization of terms of payment of works and services [7].

Industry or sector-level negotiations cover various companies in an industry. Industry-level bargaining includes a range of bargaining patterns and results in standardisation of the terms of employment and working conditions in 1 industry or sector (cotton, jute: textiles and transport are some industries in India in which such agreements commonly take place; in the oil sector such negotiations are never conducted), and hence produces a latent cartelisation' among employers as thus wages are eliminated from competition.

Depending on the issue that become the subject of negotiations, the latter can be done on a subregional, regional or even national level. National-level negotiations usually take place in the industries or sectors which are controlled by the Government and involve more than 1 national-level trade union federations and employers' organisations with the objective of fulfilling macroeconomic goals and the creation of employment with low costs. Examples of sectors in the Indian economy where national-level bargaining is common are iron and steel, postal department, banks, ports and docks, most of the mining industry (bauxite and zinc, the oil sector and the cement industry, etc.).

However, in key sectors of the economy currently there is a trend towards decentralization of collective bargaining from the industry level to the unit/plant or enterprise level. Factors contributing to this trend is the privatization of public-sector enterprises and the growth of the informal organized sector [7]. For comparison, in Russia collective bargaining is also possible at all levels of gov- 
ernence - federal, regional (interregional), industrial (intersectoral), territorial and local.

At present, China has not ratified ILO Convention No. 87 on Freedom of Association and Protection of the Right to Organize Convention or No. 98 on the Right to Organize and Collective Bargaining Convention. But in October 1997, the Chinese government signed the International Covenant on Economic, Social and Cultural Rights [8], which was approved by the Standing Committee of the NPC in February 2002. While ratifying the Covenant, the government held a view on Item 1(A) of Art 8, which stipulates, "The right of everyone to form trade unions and join the trade union of his choice, subject only to the rules of the organization concerned, for the promotion and protection of his economic and social interests. No restrictions may be placed on the exercise of this right other than those prescribed by law and which are necessary in a democratic society in the interests of national security or public order or for the protection of the rights and freedoms of others". The Chinese government stated that China would deal with this issue pursuant to its own Constitution, the Trade Union Law, 1992, Labour Law, 1994, and other related regulations [9], for instance, Provisional rules on labor contracts that created a new model of individual employment relations to replace the former system of lifetime employment and providing freedom of hiring and dismissal, the possibility of concluding fixed-term contracts and determining the conditions of labour, etc.; Rules on the procedure for settling labour disputes etc.

Labour Law of the PRC has included a Chapter on the labour and collective agreements, the right of workers to participate in the democratic management and labor through the state policy of promotion of employment but has no provisions on the right of workers to strike and pays minimal attention to issues of collective labour relations. The Law is limited itself to a general rule that "Labourers shall have the right to participate in, and organize, trade unions in accordance with the law. Trade unions shall represent and safeguard the legitimate rights and interests of labourers, and independently carry out their activities in accordance with the law." (Art 7) [9].

Article 8 of the Labour Law stipulates, "Pursuant to laws, workers take part in democratic administration through the Workers' Congress or other forms or engage in negotiation on an equal footing with the employer to protect workers' legal rights and interests". Article 6 of general provisions in the Trade Union Law, 1992, stipulates, "Trade unions shall coordinate the industrial relations and safeguard the rights and interests of employees at the enterprise through negotiation on an equal footing and the collective contract system". In the chapter concerning trade union rights and duties, Article 20 stipulates, "A trade union shall represent employees in negotiation on an equal footing and the signing of a collective contract with an enterprise or a public institution managed as an enterprise". Thus, this Act guarantees the unions a worthy place in the economic, political and social life of the country (as revised in 2001, the Law created the mechanism of action of trade unions at a level above the level of the enterprise: in some provinces there is a practice of regional collective bargaining [9]). In accordance with this Act, trade unions are aimed at the development of high ideals and morals of workers, maintenance of labour discipline, organization of socialist competition, whereas state authorities are obliged to create conditions for their activities. The Act sets out their powers in the sphere of labor relations, which, however, are of advisory nature.

The procedure of collective bargaining embodied in three articles of the Labour Law, according to which employees can conclude with the management collective agreements governing wages, working time, rest time, safety and labor protection, social insurance.

The draft collective agreement is submitted to the employees (their representatives). After being signed the collective agreement is immediately provided to the local labour state body and automatically enters into force 15 days after the receipt of its copy by the local labour state body if the latter does not raise objections or require changes to the agreement. A collective agreement concluded according to the law is binding both for the company and for its employees. The real conditions of work can't be worse than the ones fixed in the collective agreement.

Labour Contract Law of the PRC, 2007, provides for the mutual consultation of employees with the employer on the basis of equality of the parties in order to conclude a collective agreement. Thus, after bargaining on an equal basis, enterprise employees as a party and their employer unit may conclude a collective contract on such matters as remuneration, work hours, rest, leave, work safety and hygiene, insurance, and benefits. The draft of the collective contract shall be presented to an employee representatives' conference or all the employees for discussion and approval. A collective contract shall be concluded by the trade union on behalf of enterprise employees acting as a party with the employer unit. If the employer unit does not yet have a trade union, it shall conclude the collective contract with a representative chosen by the workers under the guidance of the trade union at the next higher level (Art 51). Industry-specific or area-specific collective contracts may be concluded between representatives of trade unions on the one hand and of enterprises on the other hand in such industries as construction, mining, and catering services in areas below the county level (Art 53).

As for active sectoral trade unions of China there can be called those like the trade Union of civil aviation; forestry, agriculture and water; of national security and mail; of energy resources and chemicals; of education, including physical, science, culture, health and others.

In effect, there is no legislative requirement at a national level for a minimum number of employees to set up a trade union. However, it is true that there are a number of localities where local regulations have set some minimum requirements. For instance, the Implementation of the Trade Union Law in Guangdong Province stipulates, "As for enterprises, public institutions and state organs with no trade unions, more than 10 members (who work in the present unit and are administrated by the trade union that keeps their member records) are needed to collectively petition the trade union at the next higher level to declare the establishment of a new trade union" [9]. Thus proclaimed the trade Union monopoly. Further on, the mechanism is the same as in the Labour Law, 1994: after the conclusion of a collective agreement it should be submitted to the Department of human resource management. If within 15 days after submission to the Department of human resource management the latter did not express any objection, the collective contract enters into force. A collective agreement concluded in accordance with the law is binding and must be executed by both the employer and employees. The rates and standards for remuneration and working conditions stipulated in a collective contract may not be lower than the minimum rates and standards specified by the local people's government. The rates and standards for remuneration and working conditions specified in a labor contract between an employer unit and a worker may not be lower than those stipulated in the collective contract (Art 55). If an employer unit violates the collective contract and infringes upon the labor rights and interests of its employees, the trade union may, in accordance with the law, demand that the employer unit assume liability. If a dispute over the execution of the collective contract is not resolved following negotiations, the trade union may apply for arbitration or institute legal proceedings in accordance with the law (Art 56). However, the manifested discontent of the workers proved that thus regulation is not enough. Meanwhile collective bargaining is used by the government to amortize the discontent of the workers, prevent them from the disturbance and its escalation into a social conflict.

The disadvantage of this legislation regarding collective agreements is that collective bargaining can only be conducted by trade unions and many trade union officials are appointed by the parent companies or the higher trade union-units, and thus workers are deprived of the opportunity to choose their own representatives for negotiations. In addition, collective bargaining by trade unions, 
guided and directed by the Party, is the duty which guarantees the inability of trade unions to refuse to negotiate and thus indirect control over them is provided. In this regard, it is noted [10] that "negotiations" in China are always goal-driven, and the goal (e g, salary increase) must not contradict the terms of the "broader context" (similar to the effects of collective bargaining on the level of economy in India - "objective of fulfilling macroeconomic goals"). The Party and the government of the PRC determines the priority of the "larger context" as a "negotiations" conducted by the management, not the workers. In fact, the All-China Federation of Trade Unions (ACFTU) is relied on the "top-down" approach, where the agreements of employers with the trade unions are concluded without informing or consulting with the Union members. Thus, for example, "Star Light Resin Production Company Limited" annually signs with the trade Union collective wage agreement and bonus programs based on the annual voluntary management proposals to the Union, which the latter writes into the draft of the collective agreement. During these "negotiations" the Chairman of the Union is essentially a conductor of ideas of the management, and the only task of the Union is to complete paper work in order to make the draft be in compliance with the requirements of the law. Later, the Union delivers this collective agreement to the management and asks CEOs to sign it Typically, such a contract provides fixed at the time of the "negotiations" minimum wage and other minimum conditions prescribed by the law. There are no other negotiations or discussions [11].

In South Africa currently, the legal framework of labour rights in general is created by the Constitution of 1996 [12, No. 108 of 1996], that promotes economic development and social justice and strives to meet the requirements of the ILO. The Constitution enshrines the freedom of association (art. 18) and the rights of workers to form and join a trade union and to strike, likewise trade union rights, including that "Every trade union, employers' organisation and employer has the right to engage in collective bargaining." (art 23).

SA Basic Conditions of Employment Act [13] provides that "collective agreement" means a written agreement concerning terms and conditions of employment or any other matter of mutual interest concluded by one or more registered trade unions, on the one hand and, on the other hand - (a) one or more employers; (b) one or more registered employers' organisations; or (c) one or more employers and one or more registered employers' organization." (art 1).

Labour Relations Act [14], (further on - 1995 Act) expanded the rights of trade unions, changing in their favor 1) a mechanism of solving labor conflicts and 2) the system of collective bargaining. It created machinery which makes collective bargaining not only possible but compulsory. Its aim is to avoid if possible, industrial strife and to maintain peace. Thus, it also removed the bargaining process and its outcome from scrutiny by the courts and instead subjects it to limited arbitral supervision. In 2002 the Act was amended in terms of curtailing the rights to strike in order to establish a more balance distribution of participants of labour relations thus as it is noted [15] the bargaining process became more efficient and stable.

The 1995 Act: establishes a threshold of worker rights (both individual and collective, including the right to strike); limits the employer's power to unilaterally alter terms and conditions of employment; grants the parties the freedom of contract.

As for the first of these provisions - threshold of worker rights, 1995 Act guarantees the freedom of association for both trade union and employers' organisation (art 8), provides a set of organisational rights and the right to strike.

1995 Act provides the right to association in three aspects: 1) the right to join a federation of trade unions or a federation of employers' organisations and to participate in its lawful activities, 2) the right of a registered organisation to plan and organise its administration and lawful activities [16] and 3) the prohibition of all forms of discrimination or differential treatment of persons exercising their rights under the Act.

The constitution of an organisation (unions or organisations of employers) must contain provisions according to which it's provided: that the trade union or employers' organisation, before calling a strike or lock-out, must conduct a ballot of those of its members in respect of whom it intends to call the strike or lockout (art 95(5)(p)); for appeals against loss of the benefits of membership or against termination of membership, prescribe a procedure for those appeals and determine the body to which those appeals may be made (art 95(5)(e)); members of the trade union or employers' organisation may not be disciplined or have their membership terminated for failure or refusal to participate in a strike or lockout if- (i) no ballot was held about the strike or lock-out; or (ii) a ballot was held but a majority of the members who voted did not vote in favour of the strike or lock-out (art 95(5)(q)). It's worth saying that being implicit in the constitution of an organisation a duty of fair representation would not extend to workers who are not members of trade union but who are nevertheless represented by the union in collective bargaining in terms of a collective agreement [17].

It should be noted that with regard to the legal force of the collective agreement the SA law follows the UK approach, according to which a collective agreement is a "gentlemen's agreement" and it can 't be enforced in court. Only explicit recognition of its binding force in the text of the collective agreement makes it enforceable [18]. Compliance with the agreed terms of a collective agreements are based primarily on trust, mutual respect and vigilance of trade unions and employers' organisations. This approach is based on the general bona fides civil law principle [18].

As for the right to strike, the most significant aspect of the 1995 Act's protection of strike activity is that in comparison with the 1956 Act the definition of a strike covers all forms of concerted activities aimed at resolving employment-related disputes, including a refusal to work voluntary overtime. The point is that in SAB v. FAWU it was held that a refusal to work "voluntary" overtime did not constitute a strike under the 1956 Act, becoming therefore a punishable action. At the same time not all strike activities are legal and protected (art 65(1)(c)): thus whereas the 1956 Act made no distinction between strikes over so-called "rights" and "interest" disputes, the new 1995 Act expressly prohibits strike action over the former.

However, the most important provision of the 1995 Act is that partially bans or partially allows the use of temporary replacement labour in case of an offensive lock-out (art. 76 "1. An employer may not take into employment any person- (b) for the purpose of performing the work of any employee who is locked out, unless the lock-out is in response to a strike.") that should be understood in conjunction with the provisions of the aforementioned art 95(5)(q), that stands that members of the trade union or employers' organisation may not be disciplined or have their membership terminated for failure or refusal to participate in a strike or lockout if- (i) no ballot was held about the strike or lock-out; or (ii) a ballot was held but a majority of the members who voted did not vote in favour of the strike or lock-out. The possibility of such a use of temporary replacement labour itself was the core factor that influenced the imbalance and inequality in the collective negotiation process earlier. This idea is rooted in the US law, where in 1928 in NLRB v. Mackay Radio \& Telegraph Co. it was established that employers are permitted to replace strikers permanently. It should be noted that law enforcement authorities of South Africa often take the side of the employees when dealing with conflicts arising from the implementation of temporary employment contracts. It was like that in Nkopane vs. Independent Electoral Commission - a case on the compensation for dismissal before the expiry of the term of the contracts; in National Union of Metalworkers of SA vs. SA Five Engineering Ltd - a case on the recognition of the termination of an employment contract fair due to premature execution of the obligation specified in it; in Feni v SA Five Engineering on the recognition of the permanent nature of 
the working relations entered into on the basis of monthly fixedterm contracts. But as we see, these decisions are made in individual, not with regard to collective labor disputes [19].

In this regard the question is whether the 1995 Act should prohibit the use of the replacement labour. On the one hand the use of replacement labour does not deprive workers of the right to picket to discourage the use of replacements, unions are permitted to discipline members who ignore a strike endorsed by the majority of union members, while employers are generally prohibited from disciplining any worker who refuses to do the work of someone on strike (art 187(1)(b)), on the other, a total ban on the use of replacement labour will lead to the fact that the employer will be denied the right to do business. Thus, the solution should be based on the consideration of the interests of state policy in this matter (this concept looks similar to the objectives of macroeconomic indicators in India or the terms of the "broader context" in China $[16,20]$

And here we are to come to the second of the aforementioned provisions - limiting the employer's power to unilaterally alter terms and conditions of employment, - 1995 Act limits an employer's ability to act unilaterally like this: 1) strikes and lock-outs are subjects to the same requirements, but a lesser status is at tributed to the lock-out in fact, practically it means that a) the 1995 Act permits offensive and defensive lock-outs, prohibiting so-called termination lock-outs and banning the use of temporary replacement labour in case of an offensive lock-out while workers may not be discriminated against for exercising the right to strike b) employers who decide to lock workers out may be targeted for picketing, product boycotts, etc. as it was mentioned before; 2) workers and trade unions can temporarily halt the unilateral implementation of changes to terms and conditions of employment, pending compliance with agreed or statutory conciliation procedures (art 64(4)) (so-called status quo remedy).

As for the third of the aforementioned provisions - freedom of contract, - 1995 Act recognises both freedom to contract as well as freedom of contract and consequently does not compel bargaining over terms and conditions of employment. 1995 Act establishes a framework for bargaining at sectoral level, regulates certain forms of bargaining conduct, but leaves the decision to bargain to the parties (unlike China, for example). Now employers and unions may expressly accept to include the obligation to bargain collectively in good faith in their agreement, in this case a "refusal to bargain" unfaithfully may become subject to arbitral intervention in accordance with art 24(1), that is of an advisory nature.

The 1995 Act protects the collective bargaining process from intrusion by the courts, when refusal to bargain takes place and when based on residual unfair labour practice concept compulsory binding arbitration of all disputes involves the "interpretation or application" of collective agreements [21, 22].

Given the fact that all agreements must be lawful, i.e. not contrary to law and public policy, arbitrators have broad authorities in the development of the state strategy in the sphere of collectivecontractual regulation. However, the arbitrators (even taking into account the fundamental rights of certain workers) are not entitled to suggest the parties at their discretion such conditions, which the parties do not want.

As for the content of collective agreements, it can be made up by the parties themselves. The 1995 Act even allows for collectively agreed limitations on certain constitutionally guaranteed rights, for instance: 1) where a collective agreement determines that the issue in dispute is not strikeable a strike may be prohibited; 2) by the agreement of an employer and a majority union such a limitation may also be extended to workers who do not belong to the union concerned; 3) trade unions which do not represent the majority of employees in a workplace may be deprived of the right to organise on the shopfloor if an employer and majority union agreed to grant exclusive rights to the majority union. This approach of single union bargaining is well-known in the US and UK law. Several trade unions can be represented in one company in the US, but for the process of negotiations with the employer the most representa- tive trade Union is elected, being empowered to negotiate on behalf of all the employees with which the employer is obliged to negotiate. A similar system of collective bargaining is applied in the UK, provided that one of the unions and the employer conclude an agreement on exclusive representation. Thus, usually, trade union recognition as an exclusive representative is accompanied by the waiver of the right to strike for the term of the concluded agreement likewise a consent to conduct a so-called pendulum arbitration [23] is enshrined in the collective agreement.

A conscious rejection of a thoughtful analysis of some fundamental positions of the collective agreement (from both the arbitrators and the parties), clearly visible also in its legal description, which is mentioned above, - that is collective agreement is a gentlemen's agreement, although according to the law collective agreement must be in writing and therefore is considered a contract binding the parties and other subjects who have concluded the contract (Art 23 of the Law 1995).

\section{Conclusion}

Thus, in view of the national tradition a supranational level of collective bargaining in India is not represented. In the absence of such a perspectives it would be practically useful for TNCs and their businesses to use applicable law as follows: questions of the companies' charters to be regulated by the law of the country where the company is domiciled; measures for improvement of working conditions to be regulated by the law of the country in which they are taken; the establishment of separate working conditions such as wages, for instance, to be regulated on the basis of the principle of autonomy of will; the issue of workers' participation in enterprise management (involvement through the participation in the governing bodies), - by the law which is applied to the company, that is, as a rule, the law of the location of the management board of the enterprise. In all other cases applicable law is to be determine on the basis of the connecting factor of the "closest connection".

China's national features and mentality, habits, patterns of behavior lead to the fact that even within the country trade unions' activities and its outcome - collective bargaining - are in their infancy and development, and (as in India) a supranational level of collective bargaining is not represented yet, that is, perhaps, connected with the Confucian tradition "to expect generosity from the stronger" - in our case - the employee waits generosity from the employer, that does not require any additional legal regulators in terms of worldview and philosophy.

Collectively-contractual regulation of South Africa is based at present both on the doctrines known within the legal systems of common-law countries (that is single union bargaining, employment of a replacement labour, etc.) and on the ideas close to the mentality of other BRICS countries of the (that is the fulfillment of the macroeconomic indicators in India; the terms "a broader context" in China, etc.). This situation allows to suppose the development of such a regulation in the direction coinciding with the approach of other modern states while South Africa tries to overcome historical disparities, including those in the labour market, through changes in the current labor legislation, that are corrected by its implementation. Both likely in modern reality the prospects of an international collective-contractual regulation is not the solution of the present.

\section{References}

[1] Ufimskaya Deklaratsiya IV Profsoyuznogo foruma stran BRIKS [Ufa Declaration of the Fourth BRICS Trade Union Forum] BRICS 2015. http://brics2015.ru/load/361083. Accessed June 26, 2018.

[2] T.Ya. Khabrieva (ed.), BRIKS: kontury mnogopolyarnogo mira: monografiya [BRICS: contours of the multipolar world: monograph], Moscow, 2015. 
[3] I.Ya. Kiselev, Sravnitelnoe mezhdunarodnoe trudovoe pravo [Comparative international labor law], Delo, Moscow, 1999.

[4] K.M. Belikova, Razreshenie trudovykh sporov $s$ uchastiem inostrannogo elementa $v$ stranakh BRIKS na primere Rossii, Indii i YUAR [The resolution of labor disputes involving a foreign element in the BRICS countries on the example of Russia, India and South Africa], Pravo I politika 2(195) (2016) 254-261.

[5] Jha. Kinshuk, Collective Bargaining Process in India: A Critique, 2008.

[6] AIR 1965 Mad 111 and IILLJ 136 Mad (1962). Indian Kanoon. https://indiankanoon.org/doc/1171424/. Accessed 26 June, 2018.

[7] P. Ghosh, S. Nandan, Industrial Relations and Labour Laws, McGraw-Hill Education, 2015.

[8] Resolution 2200 A (XXI) of General Assembly on 16 December 1966.

http://www.un.org/ru/documents/decl_conv/conventions/pactecon.s html. Accessed June 26, 2018.

[9] J. Qiao, Q. Zheng, Y. Jiang. Report on the Survey on Industrial Relations in East Asia. Collective Bargaining in China. http://apirnet.ilo.org/resources/china-survey-on-collectivebargaining-institutions-and-practice-2006-7/at_download/file1. Accessed June 26, 2018.

[10] Kuda idet reforma profsoyuzov i trudovogo zakonodatel'stva v $\mathrm{Ki}$ tae? [Where is the reform of trade unions and labor legislation in China?]. Global Labour University. http://columnru.global-labouruniversity.org/2013/04/blog-post_5231.html. Accessed June 26, 2018.

[11] W. Qingjun, Corporate Governance and Trade Unions in Foreign Companies in China, Proceedings of the 7th International Conference on Innovation \& Management, Wuhan, 2010, 903-912.

[12] Constitution of the Republic of South Africa, 1996 [No. 108 of 1996] - $\quad$ G17678. SAFLII http://saflii.org/za/legis/num_act/cotrosa1996423/. Accessed June 26, 2018.

[13] Basic Conditions of Employment Act. South African Department of Labour. http://www.labour.gov.za/DOL/downloads/legislation/acts/basicconditions-of-employment/Act $\% 20$ $\% 20$ Basic\%20Conditions \%20of\%20Employment.pdf. Accessed June 26, 2018

[14] Labour Relations Act. South African Department of Labour http://www1.chr.up.ac.za/undp/domestic/docs/legislation_30.pdf. Accessed June 26, 2018.

[15] B. Jordaan. Collective bargaining under the new Labour Relations Act: The resurrection of freedom of contract. SAFLII. http://www.saflii.org/za/journals/LDD/1997/2.html. Accessed June 26, 2018.

[16] K.M. Belikova, Pravo mezhdunarodnykh kollektivnykh dogovorov: perspektivy dlya Kitaya [The Law of International Collective Bargaining: Prospects for China], Legislation and the Economy 8 (2016) 62-68

[17] S. Godfrey, J. Theron, M. Visser. The State of Collective Bargaining in South Africa. An Empirical and Conceptual Study of Collective Bargaining. https://open.uct.ac.za/bitstream/item/7388/DPRU_WP07130.pdf?sequence=1. Accessed June 26, 2018.

[18] Trade Union and Labour Relations (Consolidation) Act 1992. UK Legislation. http://www.legislation.gov.uk/ukpga/1992/52/contents. Accessed June 26, 2018.

[19] M. Dubinskaya, Obzor sudebnoy praktiki Avstralii, YUAR i stran Evropeyskogo Soyuza po sporam, svyazannym s zaklyucheniem srochnogo trudovogo dogovora s rabotnikom [Review of the judicial practice of Australia, South Africa and the European Union countries on disputes related to the conclusion of a fixed-term employment contract with an employee], All about labor rights 3 (2012) 24-28

[20] K.M. Belikova, K voprosu o vozmozhnosti nadnatsional'nogo kollektivno-dogovornogo regulirovaniya trudovykh otnosheniy $\mathrm{v}$ stranakh BRIKS (na primere Indii) [On the possibility of supranational collective-contractual regulation of labor relations in the BRICS countries (by the example of India)], Gaps in Russian legislation 5 (2016) 112-119.

[21] J. Maree. Is there a Future for Collective Bargaining in South Africa? Labour Law Conference. http://slideplayer.com/slide/6118508/. Accessed June 26, 2018.

[22] S. Godfrey, Collective Bargaining in South Africa: Past, Present and Future?, Juta, 2010.

[23] I.M. Osadchaya (ed.), Ekonomika [Economics], 2000. 